\author{
Валерій Кононенко \\ Вінницький державний педагогічний університет імені Михайла Коцюбинського \\ доктор історичних наук, професор (Україна) \\ e-mail: valerii.kononenko@vspu.edu.ua \\ ORCID: https://orcid.org/0000-0001-5177-2885 \\ ResearcherlD: http://www.researcherid.com/rid/M-5954-2018 \\ Scopus Author ID: https://www.scopus.com/authid/detail.uri?authorld=57215723664

\section{Національна політика українських радянських державних утворень на етапі становлення більшовицького режиму (1917-1920рр.)}

\begin{abstract}
Анотація. Метою статmі $\epsilon$ аналіз державної політики стосовно національних меншин України українських радянських державних утворень у період становлення радянської влади в Україні. Автор досліджує особливості процесу формування, змін національної політики більшовиків напередодні жовтневого перевороту 1917 р., під час функціонування Української народної республіки Рад (УНР Рад) та Української Соціалістичної Радянської Республіки (УСРР). Методологія дослідження грунтується на поєднанні загальнонаукових та спеціально-історичних методів наукового дослідження. Використовуючи метод контентаналізу, проаналізовано основні нормативно-правові акти українських радянських державних утворень періоду утвердження більшовицького режиму та акцентовано увагу на провідних принципах та положеннях радянської національної політики. Наукова новизна роботи полягає у тому, що автор зосередив свою увагу на питанні про еволюцію та функціонування національної політики більшовиків в Україні, залежно від внутрішніх та зовнішніх фракторів, що були супутніми при встановленні радянського режиму в Україні у 1917-1920-х рр. Висновки. Вважаємо, що політика українських радянських державних утворень періоду утвердження більшовицького режиму стосовно національних меншин України була неодмінною складовою національної політики більшовиків РРФСР. Загравання до національновизвольних рухів колишніх народів Російської імперії через пправо на самовизначення» та «право на національно-культурне життя» слабшало зі становленням та утвердженням більшовизму в Україні, а з переходом до фрази військового комунізму - фрактично зникло взагалі. Віра в швидку та «тріумфральну» майбутню світову перемогу комунізму, який серед іншого передбачав ліквідацію національних відмінностей між членами комуністичного суспільства, позбавила українських більшовиків на етапі утвердження радянської влади в Україні можливостей формування чітких основних принципів та положень національнокультурної політики щодо етнічних меншин. Збереження "самостійницького» статусу радянської України часів УНР Рад та УСРР було ніщо іншим, як тактичним кроком у процесі «зближення» національних радянських утворень, у закономірному процесі об'єднання заради перемоги комунізму.
\end{abstract}

Ключові слова: більшовики, національна політика, українські радянські державні утворення, УНР Рад, УСРР.

Постановка проблеми. Національна політика усіх радянських державних утворень на території України була нерозривною складовою загальної політики Радянської Росії. Усі радянські утворення, що з'являлися в Україні з січня 1918 р., стали сателітами Радянської Росії та існували лише за її політично-ідеологічної, фрінансово-матеріальної та військової підтримки. Національна політика більшовиків на початковому етапі становлення радянської влади на словах була направлена на загравання до національних почуттів народів колишньої імперської Росії та навіть світового пролетаріату, з іншого - на намагання втримати в орбіті більшовицької політики колишні території імперії як важливі економічні ресурси для існування та зміцнення радянської влади, а також як закономірний процес «зближення» радянських режимів унаслідок перемоги комунізму, коли усі національні відмінності усуваються. Тут доволі красномовними $\epsilon$ слова стосовно долі України цього періоду одного із ідеологів більшовизму - Л. Троцького: «У нас надто багато спільних ворогів, щоб ми могли собі дозволити розкіш роздрібнювати наші сили», «Звісно, товариші, не національне питання наша основна мета. Мета наша - це комунізм. Соціальне, а не національне питання - основа, на якій ми стоїмо» [Пілаш, $2013: 76,103]$.

На нашу думку, дослідження питання про становлення національної політики перших українських радянських утворень сприятиме з'ясуванню причин утвердження радянського режиму на території України та поразки Національно-визвольної революції 1917-1920 рр. 
Аналіз джерел та останніх досліджень. Питання стосовно національної політики більшовиків загалом достатньо відображене в історичній науці. Проте серед масиву праць переважають дослідження, які спрямовані на встановлення загальних положень національної політики радянської влади, або її особливостей у період «коренізації», репресій під час 1930-х та 1940-х рр. Однією із перших питання щодо національної політики більшовиків в Україні зазначеного періоду порушила 3. Олійник. Та у своїй праці «Національна політика більшовиків в Україні в 1917-1920 рр.» автор більше зосередила увагу на відношенні більшовицької партії до українського національного питання та проаналізувала залежність змін національної політики більшовиків України від внутрішніх та міжнародних подій [Олійник, 2002]. У схожому контексті аналізує радянську національну політику у своїй праці «Національна політика більшовиків в Україні під час створення комуністичного ладу» відомий український історик С. Кульчицький [Кульчицький, 2005]. Один з головних посилів його дослідження полягає у тому, що більшовики були прибічниками унітарної держави, а уся підтримка на початковому етапі державотворчих процесів гноблених царизмом народів потрібна для захоплення влади.

Питання щодо принципів національної політики більшовиків стосовно України, загальних положень національної політики українських радянських державних утворень, принципів національно-культурної політики порушує Г. Єфіменко. Він вважає, що в основі національної політики цього періоду було уникнення «лобового» зіткнення з національно-визвольним рухом народів Росії та залучення його прихильників на свій бік [Єфріменко, 2012].

У роботі також використано наукові доробки М. Боровика та Т. Іванової, які стосуються загальних теоретичних питань національної політики більшовиків в Україні та СРСР.

Джерельною базою нашого дослідження стали нормативно-правові акти українських радянських державних утворень зазначеної доби.

Метою статті $\epsilon$ аналіз державної політики стосовно національних меншин України українських радянських державних утворень періоду становлення радянської влади в Україні.

Виклад основного матеріалу. Національна політика більшовиків не була постійною та змінювалась залежно від поставлених завдань перед партією. Загалом їх національна політика вже стала предметом дослідження автора у праці «Національна політика більшовиків та її трансформація: від РСДРП до РКП (б)» [Кононенко, 2006 : С. 232-236 ], де охарактеризовано основні періоди ії становлення. Проте, на нашу думку, видається доцільним повернення до тлумачення більшовиками національних процесів саме напередодні встановлення радянської влади, що значно спростить розуміння загальних принципів національної політики радянської влади у досліджуваний період.

Українські більшовики, на відміну від українських соціал-демократів, соціалістівреволюціонерів та створених у добу Української революції крайніх лівих Української комуністичної партії (боротьбистів) та Української партії лівих соціал-революціонерів (борбистів), у національному питанні стояли виключно на позиціях РСДРП (б). Їх програмні засади були співзвучні з позицією більшовиків Росії. Проте на етапі підготовки до більшовицького перевороту позиція РСДРП стосовно національного питання декілька разів суттєво корегувалася. Так, у прийнятій програмі партії на другому з"їзді у серпні 1903 р. національним меншинам проголошувалося широке місцеве самоврядування для місцевостей, які відрізняються побутовими умовами та національним складом населення; повну рівноправність усіх громадян незалежно від статі, релігії, раси та національності; право на отримання освіти рідною мовою; право кожного використовувати рідну мову на зборах; запровадження рідної мови в усіх місцевих та державних установах; право на самовизначення усіх націй, які входять до складу держави [Нам, 2016 : 66]. Резолюція з національного питання об'єднаного з'їзду РСДРП 1629 серпня 1917 р., зауваживши, що «повне вирішення національного питання і усунення національних конфрліктів може бути досягнуто лише з ліквідацією основ капіталістичного ладу», декларувала, що РСДРП домагається «повної рівноправності національностей, широкої територіальної автономії для областей, що відрізняються своїм національним складом, а також господарсько-побутовими умовами, при гарантії загальнодержавних законів дійсного захисту прав національних меншин на основі принципу культурно-національної автономії» [Нам, $2016: 164]$.

Позиція більшовиків напередодні жовтневого перевороту окреслена конфреренцією РСДРП (б) 21-29 квітня 1917 р. і вже показала суттєву відмінність від позиції інших членів РСДРП. Окрім того, не було одностайності й серед самих більшовиків. Так, озвучена Г. Пятаковим резолюція, що підготовлена секцією з національного питання конфреренції, проголошувала, що єдиним дієвим методом вирішення національного питання $є$ метод соціалістичної революції під гаслом «геть кордони», оскільки лише у такий спосіб міг бути знищений імперіалізм. Запропонована Резолюція пропонувала не визнавати національнокультурну автономію, яка неодмінно привела б до розмежування робітничого класу за національними ознаками та посилення їхнього зв'язку з буржуазними національними культурами 
та рекомендувала вважати «право націй на самовизначення» просто фразою, без всякого певного змісту» до вироблення загальних принципів національної політики. Утім, більшістю голосів була прийнята більш «лояльна» до національних меншин редакція документу, яка натомість визнавала за усіма націями, що входили до складу Росії, «право на вільне відокремлення та утворення самостійних держав» з урахуванням партією пролетаріату інтересів усього суспільного розвитку та класової боротьби пролетаріату за соціалізм в кожному конкретному випадку реалізації такого права. Одночасно вона відкидала право народів на національно-культурну автономію в межах однієї держави через озвучені вище причини [Нам, 2016 : 168-169].

Очевидно, що проголошуючи право на відокремлення та самовизначення ідеологи більшовизму вважали, що національний пролетаріат, дотримуючись принципу інтернаціоналізму, у більшості випадків на це не піде, а забороняючи принцип національнокультурної автономії, вони ще не достатньо розуміли міць національно-визвольних рухів серед народів колишньої Росії. Окрім того, більшовики намагалися обходити національні питання, вважаючи, що їхня революція має насамперед соціальний характер. М. Боровик вважає, що до моменту приходу більшовиків до влади, їхні лідери на національному питанні особливо не наголошували, а «гасло самовизначення націй було радше інструментом підриву Тимчасового уряду, ніж більшовицькою стратегією» [Боровик, 2020 : 172].

Із захопленням влади в Росії прийнятті перші нормативні акти, які офріційно проголошували рівність національним меншинам, проте не визначали загальних принципів національної політики радянської влади. Саме вони стали програмними документами у національному питанні для українських більшовиків. Так, вже 28 жовтня 1917 р. у зверненні «Робітникам, солдатам і селянам!» Другого Всеросійського з"їзду рад робітничих і солдатських депутатів проголошено, що радянська влада забезпечить усім націям, які проживають в Росії, «справжнє право на самовизначення» [Валк, $1957: 8]$. Дещо розширила головні гасла більшовиків у сфрері національної політики «Декларація прав народів Росії» від 15 листопада 1917 р. Вона проголошувала, що в основі національної політики будуть рівність і суверенність народів Росії; право народів Росії на вільне самовизначення, аж до відокремлення та утворення самостійної держави; скасування всіх і всяких національних і національно-релігійних привілеїв і обмежень; вільний розвиток національних меншин і етнографічних груп, що населяють територію Росії [Валк, 1957 : 40]. Зауважимо, що перша радянська Конституція РСФРР від 10 липня 1918 р. загалом не підтвердила проголошені раніше принципи національної політики, завуальовано заявивши, що «Російська Радянська Республіка засновується на основі вільного союзу вільних націй як федерація Радянських національних республік», підтримавши «повну незалежність Фінляндії», «виведення військ з Персії», «свободу самовизначення Вірменії» та проголосивши право націям Росії на власному з'їзді Рад визначитись із входженням до РСФРР [Кукушкин, Чистяков, $1987: 240,242]$.

Становлення радянської влади в Україні формально розпочалося з грудня 1917 р., коли І Всеукраїнським з'їздом рад 24-25 грудня 1917 р. у м. Харкові проголошено утворення УНР Рад робітничих, селянських, солдатських та козачих делегатів (Української Народної Республіки Рад). Першим радянським урядом України став Народний секретаріат. 29 грудня 1917 р. Рада Народних Комісарів (РНК) Радянської Росії схвалила утворення «справжньої» Української Народної Республіки «Привітанням робітничій і селянській Раді», пообіцявши братську допомогу та всіляку підтримку. У той же день телеграмою ще раз надіслано привітання від РНК Росії та обіцянку, що відтепер «гроші будуть пересилатися на ім'я уряду України, тобто Центрального виконавчого комітету України». Окрім того, ЦВК України пообіцяли включити їх представника до делегації на переговори з Німеччиною [Валк, $1957: 245-246]$. Фактичне дублювання у назві держави та уряду назв, прийнятих Центральною Радою, було спробою залучення на свою сторону частини прихильників українського національно-визвольного руху. Так, С Кульчицький розглядає «радянську державність національного характеру» у цей період як «суто тактичний захід, розрахований тільки на період боротьби з Центральною Радою» [Кульчицький, 2005 : 8]. 3. Олійник, аналізуючи політику більшовиків у 1917-1918рр. робить висновок, що «політика більшовиків щодо України після жовтневого збройного повстання визначалася не стільки з точки зору ідеологічних принципів, як з практичних обставин» [Олійник, $2002: 10]$.

Тодішній голова ЦВК УНР Ю. Медведєв як учасник переговорів у Брест-Литовську у складі делегації Радянської Росії одразу підтвердив, що УНР Рад дотримуватиметься принципів радянської політики, фрактично заявивши про встановлення федеративного зв'язку з Росією словами, що «глибоко помиляються ті, хто вважає, що тільки пута царизму пов'язували Росію $з$ Україною. Ці пута впали, але глибокий економічний і культурний зв'язок між братніми народами залишився, і в наш час цей зв'язок закріплюється на засадах вільної угоди» [Пілаш, 2013 : 65].

Повноцінним початком утвердження радянської влади в Україні став 1919 р. Із завершенням Першої світової війни, поразкою у ній Німеччини та Австро-Угорщини, 
революціями у цих країнах влада Радянської Росії вже не була зв'язана умовами Брестського мирного договору. 6 січня 1919 р. в умовах другої фази війни з УНР створений наприкінці листопада 1918 р. у Курську Тимчасовий Робітничо-Селянський Уряд України за військової допомоги Червоної Армії проголосив утворення Української Соціалістичної Радянської Республіки (УСРР).

Прикметно, що Тимчасовий уряд України у своїх декретах всіляко нагадував про тісний зв'язок із Росією, приймав декрети та постанови, які стосувалися переважно питань соціальноекономічного розвитку, встановлення диктатури пролетаріату, але волів не згадувати та не акцентувати увагу на національному питанні в Україні. Так, у першому документі новоствореного радянського утворення в Україні «Маніфесті Тимчасового РобітничоСелянського Уряду України» від 29 листопада 1918 р. жодним словом не згадувалися національні меншини та навіть натяку не було на принципи національної політики. Вперше окремі ії положення озвучені лише в «Декларації Тимчасового Робітничо-Селянського Уряду України» від 26 січня 1919 р., де проголошено ліквідацію «національного гніту, як маски класового панування» та зверталась увага на те, що мова викладання у школах залежатиме від рішення місцевого робітничого та селянського населення, а у вищій школі будуть створюватися паралельні курси різними мовами викладання [Собрание узаконений и распоряжений, $1919: 49$ ]. Проте навіть державне регулювання у сфері визначення мови викладання у закладах освіти йшло вкрай обережно. Так, наприклад, один із перших нормативно-правових актів у галузі освіти «Про середню освіту (тимчасове положення)», що був затверджений у січні 1919 р., не тільки не регулював питання освіти національних меншин, а й жодним словом не вказував на мову викладання. До того ж у Положенні була вказівка, що «все внутрішнє (педагогічне, адміністративне, господарське) життя середніх навчальних закладів усіх типів в рамках постанов центральної та місцевої влади переходить у відання педагогічних рад...» [Собрание узаконений и распоряжений, 1919 : 62]. Лише постановою Народного комісаріата освіти «Про обов'язкове вивчення в школах місцевої мови, а також географрії та історії України» надано право населенню на місцях «визначати мову, на якій буде вестись викладання в школі». При цьому мали бути враховані інтереси усіх національних груп [Собрание узаконений и распоряжений, 1919 : 348].

Г. Єфріменко переконаний, що відсутність чітких принципів національної політики у цей час пояснюється, насамперед, тим, що комуністичні керівники України у 1919 р. переживали період «запаморочення від успіхів» та вважали, що сприяти національно-культурному розвитку українців немає сенсу, оскільки незабаром буде побудовано комунізм з єдиною мовою та культурою. Для підтвердження своєї думки він наводить слова очільника уряду УСРР Х. Раковського у березні 1919 р.: «Ми покінчили з національними відмінностями, ми висунули на авансцену світової історії великі класові відмінності, розділ Європи на держави вже зникає в темряві минулого, тепер поділ проходить не за кордонами, він проходить за класами» [Єфіменко, $2012: 121$ ]. Але саме український фрактор, на думку М. Боровика, відіграв вирішальну роль в усвідомленні більшовиками політичної ваги національного питання, оскільки влітку 1919 р. «масове селянське повстання проти більшовиків під національними гаслами повалило їхню владу в Україні й мало не призвело до падіння режиму в Росії» [Боровик, 2020 : 173].

Перша українська радянська Конституція УСРР 1919 р. отримала «мінімальний» набір положень щодо національної політики. Так, стаття 4 проголошувала, що «рішуче пориваючи 3 минулим, прагнучи знищити, разом з поділом суспільства на класи, також національний гніт і національну ворожнечу, Українська Соціалістична Радянська Республіка заявляє про свій твердий намір увійти до складу Єдиної Міжнародної Соціалістичної Радянської Республіки, як тільки утворяться умови для ії̈ виникнення; разом з тим Українська Соціалістична Радянська Республіка заявляє про свою цілковиту солідарність з нині вже існуючими Радянськими Республіками і про своє рішення вступити з ними в найтісніше політичне об'єднання для спільної боротьби за торжество світової комуністичної революції і в найтісніше співробітництво у сфері комуністичного будівництва, мислимого лише в міжнародному масштабі». А стаття 32 закріплювала, що «УСРР, визнаючи рівні права трудящих незалежно від їх расової і національної належності, оголошує таким, що суперечить основним законам Республіки, встановлення або надання будь-яких привілеїв або переваг на цій основі, а також будь-які утиски національних меншин або обмеження їх рівноправності» [Собрание узаконений и распоряжений, $1919: 276,281]$. Очевидно, що саме віра в перемогу комунізму та усунення згодом будь-яких національних відмінностей стала причиною того, що у Конституції не відображено основні питання національно-культурної політики щодо національних меншин республіки. «Я думаю, що якщо ми будемо турбуватися про культуру кожної нації в окремості, то це буде нездорова національна відрижка», - заявив Нарком юстиції УСРР О. Хмельницький на пропозицію щодо внесення до Конституції положень з питань національно-культурної політики щодо етнічних меншин України [Єфріменко, 2012 : 121]. 
Загравання до національних почуттів інших народів зазвичай відбувалося в кризові часи для радянської влади. Так, наступний раз про «рівноправність» та «право націй на самовизначення» пролунало під час радянсько-польської війни 1920 р. В умовах наступу об'єднаного польсько-українського війська проти УСРР 4-й Всеукраїнський 3'їзд Рад робітничих, селянських і червоноармійських депутатів ще раз урочисто проголосив «перед всім світом повну рівноправність всіх народів й держав» та «право націй на самовизначення», заявивши, що «УСРР, зберігаючи свою самосійну державну конституцію, $\epsilon$ членом Всеросійської соціалістичної федеративної республіки...» [Збір законів і розпоряджень, 1920 : 345].

Проте резолюція 5-го Всеукраїнського 3'їзду Рад, якою схвалено «Союзний договір поміж УСРР та РСФРР», жодним словом не вказувала на основні напрямки національної політики після утворення союзної держави. 3'їзд спромігся лише окремою постановою схвалити роботу Народного Комісаріату Освіти, «шо прямував до усунення національної ворожнечі і до розвитку української мови, як мови більшості працюючих мас України» [Збір законів і розпоряджень, $1921: 91,107]$.

Згодом питання щодо утворення СРСР остаточно поховало становлення національної політики УСРР стосовно багатонаціонального українського народу, а черговий раз про неї згадали у період проголошення політики «коренізації», у часи нового загравання до національних почуттів радянських республік.

Висновки. Отже, вважаємо, що політика українських радянських державних утворень стосовно національних меншин початкового періоду утвердження більшовицького режиму України була неодмінною складовою національної політики більшовиків РРФСР. Загравання до національно-визвольних рухів народів та етнічних меншин через «право на самовизначення» та «право на національно-культурне життя» зникло з утвердженням більшовицького режиму. Віра в швидку та «тріумфральну» майбутню перемогу комунізму на початковому етапі існування радянської влади в Україні змусила не проголошувати будь-які зрозумілі та послідовні положення національно-культурної політики щодо етнічних меншин України. Збереження «самостійницького» статусу радянської України часів УНР Рад та УСРР було ніщо іншим, як тактичним кроком у процесі «зближення» національних радянських утворень у закономірному процесі перемоги комунізму. Проте більшовики були готові вносити корективи (переважно тимчасові) у національну політику, проголошувати нові національні гасла у часи послаблення народної підтримки для відновлення стабільності радянського режиму.

Подяка. Висловлюю щиру вдячність членам редколегії журналу за конструктивні поради, надані в процесі підготовки статті до друку.

Фінансування. Автор не отримував фрінансової підтримки для проведення дослідження і публікації цієї статті.

\section{Джерела та література:}

Боровик, М. (2020). Хто створив «радянські нації»? (теоретико-історіографрічні нотатки). Український історичний журнал. № 2. С. 169-186.

Єфіменко, Г. (2012). Комунізм vs. українське націєтворення в радянській Україні (19171938 рр.): сприяння, поборювання чи вимушене замирення? Український історичний журнал. № 2. C. 114-132.

Збір законів і розпоряджень. (1920). Збір законів і роспоряджень робітничо-селянського уряду України і уповноважених Р.С.Ф.Р.Р. за 1920 рік. Ч. 1-13. Харків: Видання Народнього комісаріяту юстиції. 377 с.

Збір законів і розпоряджень. (1921). Збір законів і розпоряджень робітничо-селянського уряду України за 1921 р. Харьков: Вторая Советская типография. № 1-15, 17, 19-20. 703 с.

Іванова, Т. Ю. (2014). Національна політика 1920-х рр. в СРСР. Науковий вісник Миколаївського національного університету імені В. О. Сухомлинського. Історичні науки. Вип. 3.38. С. 104-109.

Кукушкин, Ю. С. \& Чистяков, О.И. (1987). Очерк истории Советской Конституции. М.: Политиздат. 367 с.

Кульчицький, С. (2005). Національна політика більшовиків в Україні під час створення комуністичного ладу. Проблеми історії Украӥни: фракти, судження, пошуки: Міжвідомчий збірник наукових праць. Вип.13. С. 3-56.

Нам, И. В. (Упорядн.) (2016). Национальный вопрос в программных документах политических партий, организаций и движений России. Начало XX в.: Документы и материалы: учебное пособие. 2-е издание, исправленое и дополненое. Томск: Издательствово Томского университета, $256 \mathrm{c}$.

Олійник, 3. В. (2002). Національна політика більшовиків в Україні в 1917-1920 рр. (авторефр. дис. ... канд. іст. наук: спец. 07.00.01 - Історія України). К.: Київський національний університет ім. Тараса Шевченка. 19 с. 
Собрание узаконений и распоряжений. (1919). Собрание узаконений и распоряжений рабочекрестьянскаго правительства Украины за 1919 е./ Народний комісаріат юстиції. Киев: Печатня С. П. Яковлева. 580 с.

Пілаш, Д. М. (наук. ред.) (2013). Український Троцький. Тексти Лева Троцького про Україну: (збірник перекладів статей, виступів, промов та відозв з коментарями) / наук. ред. Д. М. Пілаш; літ. ред. С. П. Денисюк [та ін.]; перекл. з рос. А. А. Іщенко [та ін.]. Одеса: ВМВ. $167 \mathrm{c}$.

Кононенко, В. (2006). Національна політика більшовиків та ії трансформація: від РСДРП до РКП (б). Наукові записки Вінницького державного педагогічного університету імені Михайла Коцюбинського. Серія: Історія: Збірник наукових праць. Вип. ХІ. С. 232-236.

Валк С. М. (1957). Декреты Советской власти: [сборник] T. 1: 25 октября 1917 е. - 16 марта 1918 г. Москва: Государственное издательство политической литературы. 625 с.

\section{Валерий Кононенко}

Винницкий государственный педагогический университет имени Михаила Коцюбинского доктор исторических наук, профессор (Украина)

\section{Национальная политика украинских советских государственных образований на этапе становления большевистского режима (1917-1920 гг.)}

Аннотация. Целью статьи является анализ государственной политики в отношении национальных меньшинств Украины украинских советских государственных образований в период становления советской власти в Украине. Автор исследует особенности процесса формирования, изменений национальной политики большевиков накануне октябрьского переворота 1917 г., во время ффункционирования Украинской Народной Республики Советов (УНР Советов) и Украинской Социалистической Советской Республики (УССР). Методология исследования основана на сочетании общенаучных и специально-исторических методов научного исследования. Используя метод контентанализа проанализированы основные нормативно-правовые акты украинских советских государственных образований периода утверждения большевистского режима и акцентировано внимание на ее основных принципах и положениях советской национальной политики. Научная новизна работы заключается в том, что автор сосредоточил свое внимание на вопросах эволюции и функционировании национальной политики большевиков в Украине в зависимости от внутренних и внешних фракторов, которые были сопутствующими при установлении советского режима в Украине в 1917-1920-х г2. Выводы. Считаем, что политика украинских советских государственных образований периода утверждения большевистского режима в отношении национальных меньшинств Украины была непременной составляющей национальной политики большевиков РСФСР. Заигрывание с национально-освободительными движениями бывших народов Российской империи через "право на самоопределение» и «право на национально-культурную жизнь» ослабевало со становлением и утверждением большевизма в Украине, а с переходом к фазе военного коммунизма - фрактически исчезло вообще. Вера в скорую и «триумфральную» будущую мировую победу коммунизма, который среди прочего предусматривал ликвидацию национальных различий между членами коммунистического общества, лишила украинских больщевиков на этапе утверждения советской власти в Украине возможностей формирования четких основных принципов и положений национально-культурной политики в отношении этнических меньшинств. Сохранение «независимого» статуса советской Украины времен УНР Советов и УССР было ничем иным, как тактическим шагом в процессе «сближения» национальных советских образований в закономерном процессе объединения ради победы коммунизма.

Ключевые слова: больщевики, национальная политика, украинские советские государственные образования, УНР Советов, УССР. 
Valerii V. Kononenko

Vinnytsia Mykhailo Kotsiubynskyi State Pedagogical University $\operatorname{Dr}$ (History), Professor (Ukraine)

\title{
National Policy of Ukrainian Soviet State Formations at the Stage of Formation of the Bolshevik Regime (1917-1920)
}

\begin{abstract}
The aim of the article is to analyze the state policy towards the national minorities of Ukraine of the Ukrainian Soviet state formations of the period of formation of the Soviet goverment in Ukraine. The author explores the peculiarities of the formation and change of the national policy of the Bolsheviks on the eve of the October coup of 1917 and during the functioning of the Ukrainian People's Republic of Soviets (UPR Soviets) and the Ukrainian Socialist Soviet Republic (USSR). The research methodology is based on a combination of general scientific and special-historical methods of scientific research. Using the method of content analysis, the main Bolshevik legal acts of the period of establishment of the Bolshevik regime are analyzed, which reflect the basic principles and provisions of the national policy of the first Ukrainian Soviet state formations on the territory of Ukraine. The scientific novelty of the work is that the author focused on the evolution and functioning of the national policy of the Bolsheviks in Ukraine depending on internal and external factors that were associated with the establishment of the Bolshevik regime of 1917-1920's. Conclusions. We believe that the policy of the Ukrainian Soviet state formations during the period of establishment of the Bolshevik regime towards the national minorities of Ukraine was an indispensable component of the national policy of the Bolsheviks of the RSFSR. The flirtation with the national liberation movements of the former peoples of the Russian Empire through the «right to self-determination" and the "right to national and cultural life" weakened with the stages of Bolshevism in Ukraine, and disappeared altogether with the establishment of the Bolshevik regime. Belief in the rapid and «triumphant" future victory of communism at the initial stage of Soviet rule in Ukraine deprived the Ukrainian Bolsheviks of the opportunity to determine the basic principles and provisions of national and cultural policy toward Ukraine's ethnic minorities. Preserving the «independent" status of Soviet Ukraine during the Soviet Union and the Ukrainian SSR was nothing more than a tactical step in the process of "convergence» of national Soviet formations in the natural process of victory of communism.
\end{abstract}

Key words: Bolsheviks, national policy, Ukrainian Soviet state formations, UPR Soviets, USSR.

References:

Borovyk, M. (2020). Khto stvoryv «radianski natsii»? (teoretyko-istoriohrafichni notatky) [Who created the "Soviet nations»? (theoretical and historiographical notes)]. Ukrainskyi istorychnyi zhurnal Ukrainian Historical Journal. 2. 169-186. [in Ukrainian].

Yefimenko, H. (2012). Komunizm vs. ukrainske natsiietvorennia v radianskii Ukraini (1917-1938 rr.): spryiannia, poboriuvannia chy vymushene zamyrennia? [Communism Vs. Ukrainian nation-building in Soviet Ukraine (1917-1938): aiding, abetting, or forced appeasement?]. Ukrainskyi istorychnyi zhurnal - Ukrainian Historical Journal. 2. 114-132. [in Ukrainian].

Zbir zakoniv i rozporiadzhen. (1920). Zbir zakoniv i rosporiadzhen robitnycho-selianskoho uriadu Ukrainy i upovnovazhenykh R.S.F.R.R. za 1920 rik. Ch. 1-13. [Collection of laws and orders of the workers and peasants government of Ukraine and the authorized RSFRR for 1920. Ch. 1-13]. Kharkiv: Vydannia Narodnoho komisariiatu yustytsii. 377 s. [in Ukrainian].

Zbir zakoniv i rozporiadzhen. (1921). Zbir zakoniv i rozporiadzhen robitnycho-selianskoho uriadu Ukrainy za $1921 \mathrm{r}$. [Collection of laws and orders of the workers and peasants government of Ukraine for 1921]. Kharkov: Vtoraia Sovetskaia typohrafyia. № 1-15, 17, 19-20. 703 s. [in Ukrainian].

Ivanova, T. Yu. (2014). Natsionalna polityka 1920-kh rr. v SRSR [National policy of the 1920s in the USSR]. Naukovyi visnyk Mykolaivskoho natsionalnoho universytetu imeni V. O. Sukhomlynskoho. Istorychni nauky - Scientific Bulletin of Mykolayiv National University named after VO Sukhomlynsky. Historical sciences. 3.(38). 104-109. [in Ukrainian].

Kukushkin, Yu. S. \& Chistyakov, O. I. (1987). Ocherk istorii Sovetskoj Konstituczii [Essay on the history of the Soviet Constitution]. M.: Politizdat. 367 s. [in Russian].

Kulchytskyi, S. (2005). Natsionalna polityka bilshovykiv $v$ Ukraini pid chas stvorennia komunistychnoho ladu [The national policy of the Bolsheviks in Ukraine during the creation of the communist system]. Problemy istorii Ukrainy: fakty, sudzhennia, poshuky: Mizhvidomchyi zbirnyk naukovykh prats - Problems of the history of Ukraine: facts, judgments, searches: Interdepartmental collection of scientific works. 13. 3-56. [in Ukrainian].

Nam, I. V. (Uporyadn.) (2016). Natsionalnyy vopros $v$ programmnykh dokumentakh politicheskikh partiy, organizatsiy i dvizheniy Rossii. Nachalo XX v.: Dokumenty i materialy: uchebnoe posobie. 2-e izdanie, ispravlenoe $i$ dopolnenoe [The national question in the program documents of political parties, organizations and movements in Russia. Beginning of the XX century: Documents and materials: a 
textbook. 2nd edition, corrected and supplemented]. Tomsk: Izdatelstvovo Tomskogo universiteta, 256 s. [in Russian].

Oliinyk, Z. V. (2002). Natsionalna polityka bilshovykiv v Ukraini v 1917-1920 rr. (avtoref. dys. ... kand. ist. nauk: spets. 07.00.01 - Istoriia Ukrainy). K.: Kyivskyi natsionalnyi universutet im. Tarasa Shevchenka. 19 s. [in Ukrainian].

Sobranie uzakoneniy i rasporyazheniy. (1919). Sobranie uzakoneniy i rasporyazheniy rabochekrestyanskago pravitelstva Ukrainy za $1919 \mathrm{~g}$. [Collection of laws and orders of the workers and peasants government of Ukraine for 1919] / Narodniy komisariat yustitsiï. Kiev: Pechatnya S. P. Yakovleva. 580 s. [in Russian].

Pilash, D. M. (nauk. red.) (2013). Ukrainskyi Trotskyi. Teksty Leva Trotskoho pro Ukrainu: (zbirnyk perekladiv statei, vystupiv, promov ta vidozv z komentariamy) [Ukrainian Trotsky. Leo Trotsky's texts about Ukraine: (collection of translations of articles, speeches, speeches and appeals with comments)] / nauk. red. D. M. Pilash; lit. red. S. P. Denysiuk [ta in.]; perekl. z ros. A. A. Ishchenko [ta in.]. Odesa: VMV. 167 s. [in Ukrainian].

Kononenko, V. (2006). Natsionalna polityka bilshovykiv ta yii transformatsiia: vid RSDRP do RKP (b) [National policy of the Bolsheviks and its transformation: from the RSDLP to the RCP (b)]. Naukovi zapysky Vinnytskoho derzhavnoho pedahohichnoho universytetu imeni Mykhaila Kotsiubynskoho. Seriia: Istoriia: - Scientific Papers of the Vinnytsia Mykhailo Kotsyiubynskyi State Pedagogical University. Series: History. XI. 232-236. [in Ukrainian].

Valk S. M. (1957). Dekrety Sovetskoy vlasti: [sbornik] T. 1: 25 oktyabrya 1917 g. - 16 marta 1918 g. Moskva: Gosudarstvennoe izdatelstvo politicheskoy literatury. 625 s. [in Russian].

Статтю надіслано до редколегії 03.04.2021 р. Статтю рекомендовано до друку 11.05.2021 р. 